\title{
ADMINISTRATIVE PROCEDURE BEFORE THE NATIONAL LABOR RELATIONS BOARD
}

\author{
BENEDICT WOLF*
}

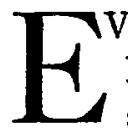

VER since it commenced to function in the fall of I935, the National Labor Relations Board has been so constantly the subject of vigorous attack and the center of widespread controversy that objective analysis of its methods of operation has been extremely rare. This has been unfortunate, since a great deal of the criticism would have been obviated if the critics had first made an effort to learn more about the Board's procedure. This procedure is set forth fully in the Board's Rules and Regulations ${ }^{\mathrm{I}}$ and is the key to the administrative policy adopted by the Board. A clear understanding of this administrative policy may help to dissipate the confusion which has been caused by the barrage of attacks against the Board.

It is of prime importance to realize that there are really two policies involved in the Board's work. One is the policy with regard to substantive matters. This is contained in the National Labor Relations Act. ${ }^{2}$ The second is the procedural policy which has been adopted to give effect to the substantive rights contained in the Act. Over the first the Board exercised no control. The second was completely within the control of the Board. There is only one standard by which the administrative policy of the Board can be judged, and that is its effectiveness in carrying out the policies adopted by Congress and set forth in the National Labor Relations Act.

Those who dislike the objectives of the Act and who disagree with its policies are likely to extend their dislike to everything connected with the Act, including the Board and all its works. However, even these individuals can demand from the Board only that its own administrative policy be framed in a manner which will carry out the mandate of the Act with least burden to all who are subject to its terms.

This article will not attempt to make a lengthy defense of the National Labor Relations Act and its objectives. However, in order to clarify some of the issues which have arisen, it becomes necessary to point out

* Member of the New York Bar; formerly Secretary and Chief Trial Examiner of the National Labor Relations Board.

× National Labor Relations Board's Rules and Regulations, Series $I$, as amended.

${ }^{2} 49$ Stat. 449 (r935), 29 U.S.C.A. r8I (I936). 
the assumption on which Congress acted when it passed the National Labor Relations Act. Congress assumed that there was an "inequality of bargaining power between employees who do not possess full freedom of association or actual liberty of contract and employers who are engaged in the corporate or other forms of ownership association"3 and stated that the protection by law of the right of employees to organize and bargain collectively would, among other things, restore equality of bargaining power between employers and employees. The restoration of this equality was, in the opinion of Congress, a desirable social result and in the Act Congress declared that the policy of the United States was to eliminate the causes of certain obstructions to commerce and to mitigate and eliminate those obstructions when they have occurred by protecting the exercise by workers of the right to self organization and by encouraging the practice and procedure of collective bargaining. ${ }^{4}$

Critics of the Act base their criticism on the ground that the Act, since it grants certain rights to employees, should simultaneously have placed upon employees certain restrictions and responsibilities or should have granted to employers certain additional rights. Obviously, the effect of placing additional restrictions on employees or granting additional rights to employers in their relations with their employees would have been to nullify the purposes of the Act. It is meaningless to criticize the Act on the ground that it is not "impartial". Congress deemed it necessary to correct certain abuses. The Act was frankly designed to correct those abuses and to increase the rights of employees in relation to the power of employers. Of necessity, a statute which is designed to correct abuses against a certain class of people must be framed for the benefit of that class. Nothing would be accomplished if the statute left the powers of that class in the same relation to the powers of other classes that existed previous to the passage of the statute. Such a statute is not intended to preserve the status quo and to criticize it on the ground that it fails so to do is meaningless.

The type of criticism which has just been mentioned was considered by the Supreme Court of the United States at the time it determined the constitutionality of the National Labor Relations Act. Mr. Chief Justice Hughes stated in the Jones \& Laughlin case: ${ }^{5}$

The Act has been criticized as one-sided in its application; that it subjects the employer to supervision and restraint and leaves untouched the abuses for which em-

3 N.L.R.A. (National Labor Relations Act) Sec. I. 4 N.L.R.A. Sec. I.

5 National Labor Relations Board v. Jones \& Laughlin Steel Corporation 30I U.S. I, 46 (1937). 
ployees may be responsible. That it fails to provide a more comprehensive plan,with better assurances of fairness to both sides and with increased chances of success in bringing about, if not compelling, equitable solutions of industrial disputes affecting interstate commerce..... We have frequently said that the legislative authority, exerted within its proper field, need not embrace all the evils within its reach. The Constitution does not prohibit "cautious advance, step by step," in dealing with the evils which are exhibited in activities within the range of legislative power.

At the time the National Labor Relations Act was passed there were many statutes and ordinances, federal, state, and municipal, which protected the rights of employers in their relations with their employees. It was the considered judgment of Congress that employers needed no further protection from the federal government and that the protection granted to employees by the Act would at most equalize the positions of the two groups. Experience in the administration of the Act and a study of its effects have shown that this position was sound. However, whether one agrees with the position or not need not be controlling in an evaluation of the administrative procedure and policy of the Board. An agency administering a statute cannot be expected to interpret it in a manner which will nullify its purpose. The utmost that can be expected is that the administration of the statute and the correction of the abuses at which the statute was aimed should be accomplished as painlessly as possible.

\section{SUBSTANTIVE RIGHTS}

In order to understand the method of administering the National Labor Relations Act, it is necessary to know something about the substantive provisions of the Act. The rights of employees are set forth in the following words:

Employees shall have the right to self organization; to form, join, or assist labor organizations; to bargain collectively through representatives of their own choosing; and to engage in concerted activities for the purpose of collective bargaining or other mutual aid or protection. ${ }^{6}$

This was a statement of existing law rather than a new Bill of Rights for employees. ${ }^{7}$

Prior to the passage of the Act, however, these rights of employees, other than those engaged in rail transportation, were not protected from nullification by employers. The National Labor Relations Act was designed primarily to afford such protection and, in order to achieve this result, Section 8 of the Act sets forth certain specific unfair labor practices and

${ }^{6}$ N.L.R.A. Sec. 7 .

'American Steel Foundries v. Tri-City Central Trades Council, 257 U.S. I84 (Ig2r); Texas \& N. O. R. Co. v. Railway Clerks, 28I U.S. 548 (I929). 
Section Io of the Act provides the means by which the agency administering the Act can prevent the unfair labor practices when they affect commerce. $^{8}$

Section 7 (A) of the National Industrial Recovery Act set forth in general terms certain basic rights of employees, and provided that Codes of Fair Competition promulgated thereunder should incorporate a statement of these rights. Experience in the administration of the National Industrial Recovery Act showed clearly the difficulty of interpreting the general language to which reference has just been made. As a result, it was determined that the National Labor Relations Act would be drafted in a manner which would eliminate as much as possible the dangers of interpreting generalities. Therefore, while Section 8 (I) of the National Labor Relations Act provides that any interference, restraint or coercion by employers in the exercise of the rights set forth in Section 7 shall be considered an unfair labor practice, the Act contains, in addition to this general prohibition, a declaration that certain specific practices by employers, which experience had shown were most frequently used to prevent or destroy union organization and union activity, are unfair labor practices.

Section 8 (2) of the Act, in an effort to abolish the evil of company dominated unions, states that it shall be an unfair labor practice for an employer "to dominate or interfere with the formation of or administration of any labor organization" or contribute financial or other support to it." Section 8 (3) of the Act states that it shall be an unfair labor practice for an employer "by discrimination in regard to hire or tenure of employment or any term or condition of employment to encourage or discourage membership in any labor organization." This section seeks to eliminate the use of discharge, lay-off, or demotion as a punishment for joining or being active in a Union or for refusing to join a union. ${ }^{\text {xo }}$ Section 8 (4) of the Act protects employees who file charges or give testimony in proceedings before the Board against discharge or other discrimination.

${ }^{8}$ The term "affecting commerce" is defined in N.L.R.A. Sec. 2 (7).

9 By definition, the term labor organization includes any organization, agency, or employee representation plan which exists even in part for the purpose of dealing with employers concerning working conditions. N.L.R.A. Sec. 2 (5).

io This section of the Act contains a proviso permitting an employer to enter into a closed shop contract with a union not formed or maintained in violation of the Act, if a majority of the employees in a proper unit belong to the union when the contract is made. Where such a contract is in existence, the employer can discharge any employee for refusing to join the union and still not be guilty of an unfair labor practice within the meaning of Sec. 8 (3) of the Act. 
Organization of employees is not an end in itself, but is intended to enable the employees to bargain collectively in an effective manner. The portions of the Act which have just been described deal with the protection of the employees in their right to self organization. After this self organization has been accomplished, the employees are in a position to demand that the employer bargain collectively with their representatives. The refusal of an employer to enter into collective bargaining negotiations would leave the employees with the choice of withdrawing their demands or striking in order to force the employer to grant them. In the hope of eliminating this particular cause of industrial strife, Congress included in Section 8 of the Act one further unfair labor practice. Section 8 (5) states that it shall be an unfair labor practice for an employer "to refuse to bargain collectively with the representatives of his employees, subject to the provisions of Section 9 (A)." This subsection deals with what is really the ultimate objective of the National Labor Relations Act, collective bargaining between an employer and the representative of his employees regarding hours, wages, and working conditions, so that changes with regard to these matters can be accomplished with the least disturbance to the normal industrial processes.

Collective bargaining can be accomplished effectively only through representatives acting on behalf of the employees. The employees en masse obviously cannot perform this task. It was, therefore, important to provide means by which the identity of the employees' representatives could be determined. Section 9 of the Act sets forth the device whereby this result can be achieved in the most peaceful manner possible.

One of the most troublesome questions that faced the National Labor Board and the old National Labor Relations Board was that of "majority rule." There was no specific instruction in Section 7 (A) of the National Industrial Recovery Act on the point. Both these agencies decided, however, that the "majority rule" was the only workable rule to follow in determining the rights of employees to collective bargaining..

There was, however, considerable controversy regarding this principle and, in order to quiet all doubts, Congress inserted in the National Labor Relations Act a definite statement that the representative chosen by the majority of the employees in an appropriate unit shall be the exclusive

Ir See In the Matter of Denver Tramway Corporation and Amalgamated Association of Street \& Electric Railway Employees of America Division roor (decided by the old National Labor Board on March I, I934), and In the Matter of Houde Engineering Corporation and United Automobile Workers Federal Labor Union No. 18839 (decided by the old National Labor Relations Board on August 30, 1934). 
representative of all of the employees in the unit for collective bargaining purposes.

Whenever a question affecting commerce arises concerning the representation of employees for the purpose of collective bargaining, the $\mathrm{Na}$ tional Labor Relations Board is empowered to investigate the question and certify the chosen representative. In order to do so, the Board must first determine which of the possible bargaining units is appropriate in the particular case, since the choice of a representative can be exercised only by the employees in that unit. One of several units may be chosen, the employer unit, the craft unit, the plant unit, or a subdivision thereof. The Act sets forth no specific rules to be followed by the Board in its determination of the appropriate unit but states as a general principle that the unit to be chosen should be that which will "insure to employees the full benefit of their right to self organization and to collective bargaining, and otherwise effectuate the policies"s2 of the Act.

The statute specifically directs that every time the Board investigates a question concerning representation it must provide for an appropriate hearing upon due notice. ${ }^{13}$ As a result of the Board's investigation and the hearing, it may direct that a secret ballot be taken. If, as a result of the investigation and hearing, the wishes of the employees are clearly apparent, the Board may decide that no secret ballot is necessary and may certify the chosen representative without holding any election.

Section 9 of the Act is meaningless except as it relates to Section 8 (5) of the Act. A certification by the Board to the effect that a certain representative has been chosen by the majority of the employees in an appropriate unit is merely a certification of a fact. It neither increases nor decreases the rights or obligations of the parties. As a practical matter, what it does is to remove from the scope of conflict one of the issues which may give rise to such conflict, and it provides a means whereby employees can make known to their employer their wishes regarding representation without use of economic force. After such a certification, the employer has no excuse for failure to carry out the mandate implicit in Section 8 (5) of the Act and is under the duty to bargain with the representative certified by the Board.

\section{ADMINISTRATIVE SET-UP}

A short description of the functions of the personnel in the Washington office and the regional offices of the National Labor Relations Board is

${ }^{2}$ N.L.R.A. Sec. 9 (B).

${ }^{13}$ N.L.R.A. Sec. 9 (C); $c f$. Railway Labor Act, 44 Stat. 577 , as amended by 48 Stat. II 85 and by 49 Stat. 1189 , Sec. 2 , Tenth. This Act contains no mandatory provision for a hearing. 
necessary for a complete understanding of the Board's method of operation.

The Board is composed of three members ${ }^{14}$ with headquarters in Washington. The Board has created several divisions in its Washington office to carry out the administration of the Act. These are the Legal, Administrative, Trial Examiner, Economic, and Publications divisions. The first three deal directly with the administration of the Act in a much greater degree than do the last two.

The General Counsel is head of the Legal Division. The work of this division is separated into two sections, litigation and review. The litigation section is responsible for the conduct of hearings before the Board and is also responsible for advising the Regional Attorneys in the field with regard to the conduct of hearings before Trial Examiners. The litigation section represents the Board in injunction suits brought against it and in proceedings in the United States Circuit Court of Appeals and the Supreme Court when actions are brought by the Board for enforcement of its orders or by parties to the proceedings for review of the Board's orders. Thus the work of this division involves both trial and appellate practice and both litigation and brief work.

The review section assists the Board in the analysis of the records of hearings conducted before Trial Examiners in the regions or before the Board in Washington. It is charged with preparing opinions on general questions of law and problems arising from the interpretation of the National Labor Relations Act and the Board's rules and regulations.

The Administrative Division, under the general supervision of the Secretary, has charge of the operation of the administrative, clerical and fiscal activities of the Board, both in Washington and in the regions. In addition, this division supervises the activities of the Regional Offices with regard to case development and the handling of labor relations problems.

The Trial Examiners Division is responsible for the conduct of hearings on formal complaints and petitions for certification of representatives. This division is under the supervision of the Chief Trial Examiner. The Trial Examiners, when they conduct hearings, act as the direct agents of the Board. The Board, or an individual member, may act as Trial Examiner.

The Economics Division, headed by the Chief Economist, prepares the economic data which is used as evidence in the Board's cases or as material for inclusion in court briefs, and advises the Board with regard to

14 At present J. Warren Madden of Pennsylvania is the Chairman of the Board and Edwin S. Smith of Massachusetts and Donald Wakefield Smith of Pennsylvania are members. 
the economic aspects of labor relations. The Publications Division has charge of the dissemination to the public of information regarding the activities of the Board and its decisions and orders.

In the Fall of I933, a few months after the National Labor Board was appointed, it became necessary to institute a system of Regional Offices in order to give proper attention to the volume of work which was coming before the Board. These offices were headed by Impartial Chairmen, who were assisted by a panel of representatives of industry and representatives of labor. The Impartial Chairmen and the representatives of industry and labor served without compensation. When the old National Labor Relations Board commenced to function in July, r934, the work in the Regional Offices had increased to the point where this system no longer was feasible, since the volunteer Regional Board members could not devote sufficient time to the work. This necessitated a modification of the system previously used. The paid Executive Secretary of the Regional Office became the administrative head of the office and a series'of threeman panels were established in each office, each panel consisting of one representative of the public, one representative of industry, and one representative of labor.

This was the set-up of the Regional Boards when the present National Labor Relations Board took office at the end of August, I935. After a survey of the situation, the Board deemed it advisable to institute a completely new system, abolishing the volunteer phase of the Regional Board personnel. The Board decided that under the new Act there would be a greater need for strict legal procedure and for uniform interpretations and rulings. The only way to insure this was to have the work performed by the regular members of the Board staff. As a result, the set-up now in force replaced the panel system.

At the present time the country is divided into twenty-two regions, with a Regional Office in each. A Regional Director is at the head of each Regional Office and is responsible for the administration of the office. He acts under the supervision of the Administrative Division of the Board in Washington. The Director is assisted in his work by several Field Examiners who participate with him in the investigation of charges of unfair labor practice and petitions for certification of representatives, and in the attempt to adjust complaints arising under the Act and to arrange for consent elections.

There is a Regional Attorney in charge of the legal work in each field office. The Regional Attorney is under the supervision of the General Counsel of the Board in Washington as well as of the Regional Director. 
This Regional Attorney, assisted by other members of the staff, acts as legal adviser to the Director with regard to the desirability of issuing complaints, drafts complaints, investigates the facts in each case with a view to determining the existence of a cause of action, prepares cases for hearing, and presents the facts at hearings before the Board's Trial Examiners. Sometimes it becomes necessary for the Regional Attorney to participate in oral argument before the Trial Examiners or to submit briefs to them. To a great extent the division in functions in the Regional Offices follows the division in functions which exists in the Washington office of the Board.

\section{ADMINISTRATIVE PROCEDURE}

The work of the Board can be separated into two fairly distinct sections. One involves action with regard to unfair labor practices listed in Section 8 of the Act, cases with reference to this phase of the work being known as "complaint cases." The other phase of the work involves cases relating to questions concerning representation, these cases being known as "representation cases." To get a clear picture of the method in which the Board operates, it is advisable to describe the procedure in each type of case from its inception to its conclusion.

\section{COMIPLAINT CASES}

The Act provides that the Board can set in motion the machinery to prevent unfair labor practices affecting commerce "whenever it is charged that any person is engaged in or is engaging in any such unfair labor practice." Is A charge may be filed by any person or labor organization with the Regional Director for the region in which the unfair labor practice has occurred. Four copies of the charge must be filed with the Regional Office, the original being signed and sworn to before a notary public or an agent of the Board authorized to administer oaths. Once the charge is filed with the Regional Director, it can be withdrawn only with his consent or the consent of the Board. The charge must contain the name and address of the party making the charge and of the party against whom the charge is made. In addition, it must contain a clear and concise statement of the facts which are alleged to be an unfair labor practice affecting commerce. ${ }^{16}$ Every charge must contain an allegation that an unfair labor practice within the meaning of Subsection I of Section 8 of the Act has been committed, since the Board deems that an employer's

is N.L.R.A. Sec. ro.

${ }^{16}$ National Labor Relations Board Rules and Regulations, Series I as amended, Article II, Sec. $1-4$. 
engaging in the commission of any of the unfair labor practices specifically prohibited by the other subsections of Section 8 amounts also to interference, restraint, or coercion of the employees in the exercise of the rights guaranteed in Section 7 of the Act and is thus a violation of Section 8 ( $\mathrm{I}$ ).

The filing of a charge in the Regional Office does not necessarily set in motion the formal procedure of the Board. Usually charges are filed in person and either the Regional Director or a Field Examiner has an opportunity to discuss the case with the person filing the charge. Sometimes such discussion reveals the fact that no unfair labor practice has actually been committed or that the Board's jurisdiction does not extend over the type of business in which the employer is involved. Frequently the Regional Director is able to persuade the aggrieved party to refrain from filing the charge, although even in such cases the Regional Director may try to adjust the matter informally either by a telephone conversation or by arranging a conference between the employer and the representative of the employees involved. Because of the position of the Regional Directors in the various communities in which they operate, they have been able to do a great deal of effective informal work of this nature and have thus helped considerably in averting and decreasing industrial strife.

If the Regional Director is unable to persuade the person filing the charge that there is not sufficient merit to warrant action by the Board and a full investigation reveals no merit or no jurisdiction, he has the right to send the party a letter formally refusing to issue a complaint. This action by the Regional Director closes the case unless the party who filed the charge desires to appeal to the Board in Washington from the Regional Director's decision. A review of the Regional Director's act can be secured by the writing of a letter to the Board in Washington, a copy of the letter being sent to the Regional Director. ${ }^{17}$ The file of the case is then transmitted to the Board and is there reviewed. If, in the Board's opinion, the Regional Director's action was unjustified, he will be ordered to issue a complaint based on the charge which had been filed. If the Board deems the Regional Director's action correct, a letter is sent to the party requesting a review, informing him of the affirmance of the Director's refusal to issue a complaint.

Upon receipt of a charge, the Regional Director initiates a complete investigation of the allegations therein contained. The investigation may be conducted by one or more Field Examiners or, if the importance of the case warrants it, by the Regional Director himself. The examiner usually goes to the particular locality where the plant is located and interviews all

${ }^{17} I d$. at Sec. 9 . 
people who may have knowledge of the circumstances surrounding the alleged unfair labor practice. He will thus meet with the Union representative, the aggrieved party, and other people working in the plant who may be prepared to testify on behalf of the party filing the charge. He will also interview the employer and any supervisory officials who may have knowledge of the facts. During the course of this investigation, the Examiner is able to get a fairly complete picture of the events and in most instances secures from the employer information which indicates whether the business of the employer falls within the jurisdiction of the Board.

This investigation serves several purposes. First, it enables the Regional Director to determine whether there is sufficient merit or jurisdiction to warrant the issuance of a complaint. Secondly, the information usually acts as the basis for the Regional Attorney's preparation of the case for trial. In addition, and this may be the most important function of the investigation, it enables the Examiner, by talking to both parties, to evolve some method of settlement. An attempt is almost always made to get the parties to a joint conference, since experience has shown that, if the parties will sit down and talk with each other about grievances that may have arisen, there is a considerable likelihood that the grievances can be adjusted. In all cases, the settlement which is finally reached must be acceptable to both parties. Furthermore, no staff member is permitted to approve a settlement which accomplishes less than full compliance with the terms of the Act. No compromise is permitted in this regard. Of course, the parties themselves may reach an agreement in some cases which does not fully comply with the terms of the Act and the Director may thereafter permit the withdrawal of the charge. However, in any case where a staff member of the Board participates in a settlement, there must be strict adherence to the Act.

The number of charges filed with the Regional Offices of the Board has become so great, particularly since the Supreme Court upheld the constitutionality of the Act in April, r937, that it has become physically impossible to take formal action in all cases. As a result, the adjustment of cases before they reach the stage where the issuance of a complaint is necessary has become a vitally important function of the Regional Offices. The statistics issued by the Board indicate that a total of ro, 568 cases have been handled by it during the twenty-six months ending December Ist, I937. More than 4,000 of the approximately 7,000 cases which have been closed were closed by agreement between the parties. Over a million workers were involved in the cases settled by the Board. It is easy to perceive the tremendous benefits deriving from the peaceful adjustment 
of labor disputes involving a million employees and the substitution of such adjustment for industrial strife. This accomplishment alone is complete justification for the work of the Board and its Regional Offices.

Where investigation of a case by the Field Examiner reveals that there is merit to the charge and that the Board would probably have jurisdiction over the subject matter, the Regional Director issues a formal complaint in the name of the Board, setting forth the unfair labor practices alleged to have occurred and containing a notice of hearing before a Trial Examiner at a definite date.

The notice of hearing which is issued with the complaint must give the respondent at least five days' notice of hearing, and the respondent has the right within five days from the service of the complaint to fle an answer. It should be noted that the respondent's failure to file an answer does not operate as an admission of the allegations of the complaint. If, however, an answer is actually filed and fails to deny specifically any allegation in the complaint or fails to state that the respondent is without knowledge with regard to that allegation, the allegation is deemed to be admitted. As a matter of actual practice, the attorneys of the Board have not attempted to rely to any great extent upon admissions contained in the answers. They have preferred to prove their cases fully, so that all the facts could be presented to the Board.

The Regional Director has the power to extend the time within which an answer must be filed and to postpone the hearing to a date later than it was originally scheduled, if the request for postponement is made prior to the actual commencement of the hearing. All motions for extension of date of hearing or date of filing answer, motions to intervene, and any other motions which the parties may desire to make prior to the hearing must be made in writing and filed with the Regional Director. The Regional Director decides motions regarding extension of hearing date or the date of filing answers, and motions to intervene. All other motions made prior to the hearing date are decided by the Trial Examiner at the hearing.

Motions which are made at the hearing must be stated orally. The exception to this rule is the motion to intervene, which must always be in writing, no matter when made. The Trial Examiner's rulings on motions are stated orally and the motions and the rulings become part of the transcript of the hearing.

A motion for intervention may be made by any person or labor organization and must set out the grounds upon which the moving party bases his interest in the proceeding. These motions may be granted in full or may be granted in limited form, as the Regional Director or the Trial 
Examiner deems proper. ${ }^{18}$ Usually in cases involving an allegation that a respondent has formed, dominated, or interfered with the administration of an alleged company union, the company union is permitted to intervene for the purpose of defending itself against the charge of being so formed or dominated.

Where the Trial Examiner grants a motion to dismiss the complaint, the party filing the charge has the right, within ten days, to request a review by the Board in Washington of this ruling. The Board may extend the period within which this request can be made where sufficient cause for such extension is shown. ${ }^{19}$ A motion of this nature is rarely granted before all the evidence has been presented.

After a definite date has been set for the hearing and the issues have been joined, a Trial Examiner is assigned to the case by the Chief Trial Examiner in Washington. There is usually no special assignment of Trial Examiners to particular regions. Available Trial Examiners are assigned to cases in the various regions, as the need arises.

In final preparation for trial, the Board issues to the Regional Attorney such subpoenas as are needed. The right to issue subpoenas is given by the National Labor Relations Act to any member of the Board..$^{20}$ Agents of the Board have the right of access to and the right to copy any evidence of any person being proceeded against which relates to matters under investigation. If parties to the proceeding (these parties include the respondent and the person filing the charge) desire subpoenas for use in preparation for trial, application for such subpoenas may be filed with the Regional Director or the Trial Examiner. The applications must be timely and must specify the name of the witness whose attendance is desired, the nature of the facts to be proved by him, and the documents desired, in sufficient detail to enable them to be identified for the purpose of production. Witnesses summoned by the Board are paid the same fees which prevail in the courts of the United States. Witness fees and mileage for witnesses summoned by the parties to the proceeding are paid by such parties. In exceptional cases testimony may be taken by deposition under oath.

After all preliminary steps have been taken, the hearing commences and is presided over by the Trial Examiner. Witnesses are examined orally under oath and are not excused from testifying because of a claim that the testimony may tend to incriminate them or subject them to a penalty or forfeiture. ${ }^{2 \mathrm{I}}$
${ }^{28} I d$. at Sec. Ig.
${ }^{20}$ N.L.R.A. Sec. II.'
${ }^{29} I d$. at Sec. I7.
${ }^{2 x}$ N.L.R.A. Sec, II. 
Proof of the allegations of the complaint is presented by the Regional Attorney and, upon completion of the Board's case, the respondent, either in person or by attorney, can present whatever defense is relevant. All parties have full opportunity to examine and cross-examine witnesses. The hearings are conducted in as informal a manner as possible within the limits set by requirements of due process and expedition.

The primary duty of the Regional Attorney is not to prove a case but to elicit all the facts. The chief purpose of the hearing is to place on the record all the facts which are relevant to the inquiry and which will be necessary to enable the Board to reach a just determination of the case. For this reason, the Trial Examiner is also placed under a duty to inquire fully into the facts and is given the power to call, examine, and crossexamine witnesses. The use of stipulations of fact is encouraged.

The National Labor Relations Act specifically provides that in proceedings before the Board the rules of evidence prevailing in courts of law or equity shall not be controlling. ${ }^{22}$ The fact that the Board is not bound by the strict rules of evidence does not mean that these rules are entirely disregarded. The hearing is kept within reasonable limits. The guide the Board follows in this respect is that which was set forth by the United States Circuit Court of Appeals. The court stated:

Evidence or testimony, even though legally incompetent, if of the kind that usually affects fair-minded men in the conduct of their daily and more important affairs, should be received and considered; but it should be fairly done. ${ }^{23}$

The provision in the Act regarding the rules of evidence follows the increasing tendency to give quasi-judicial agencies a greater freedom in the ascertainment of facts even though the method of introducing those facts into evidence could not be utilized under strict court procedure and even though such facts might under the formal rules of evidence be deemed incompetent.

All testimony taken at the hearing before the Trial Examiner is recorded and transcribed. Objections with respect to the conduct of the hearing or the introduction of evidence are noted on the record and short statements of the grounds of objection are also transcribed. The Trial Examiner has, however, the right to direct that no transcript be made of lengthy arguments on motions or objections, and can thus keep the record from being swollen by irrelevant argument and immaterial controversy. The Board's decisions must be based on the evidence, or on the validity of the particular objections made, and since in all cases the parties are given

${ }_{22}$ N.L.R.A. Sec. xo (B), Rules and Regulations Series I as amended, Article II, Sec. 26.

${ }^{23}$ John Bene \& Sons, Inc. vs. Federal Trade Commission, 299 Fed. 468 (C.C.A. 2d 1924). 
an opportunity to appear before the Board for oral argument if they wish, the Board has decided that no purpose would be served by inclusion of argument's of counsel into the stenographic transcript.

After the parties have concluded the presentation of the facts, they may, if they so desire, present oral argument to the Trial Examiner. This oral argument is rarely made part of the record. In addition, the Trial Examiner may, if he deems it advisable, permit the parties to file briefs or written statements.

The Board has no way of enforcing the subpoenas it issues. If a person who is subpoenaed refuses to appear or to produce documents, the Board must go before the appropriate United States District Court and request an order directing the person who has been subpoenaed to appear or produce documents. If the court grants this order, a failure to obey would be a contempt of court and punishable as such. Until a court order of this nature is issued, however, no penalty results from the failure of a witness to appear or produce documents. Similarly, if a witness has taken the stand and started to testify, the Trial Examiner has no way of forcing the witness to answer specific questions. To attempt to secure a court order at that stage of the proceeding would involve lengthy and harassing delays. The Board has therefore given the Trial Examiner the power to strike out all testimony previously given by a witness on related matters where the witness refuses to answer a question which has been ruled proper. The Trial Examiner also has the power to exclude from the hearing any person guilty of contemptuous conduct ${ }^{24}$ and can, if necessary, direct that the hearing shall be private rather than public, if circumstances warrant.

After the hearing has been concluded, the Trial Examiner prepares an Intermediate Report, except in instances where the case has been transferred to the Board before or during the hearing or where the Trial Examiner is specifically directed by the Board to make no Intermediate Report. This Report contains the Trial Examiner's findings of fact and conclusions of law and becomes a part of the record in the case. If the Report concludes that the respondent has not engaged in unfair labor practices affecting commerce, the case is closed unless the party who made the charge files with the Board in Washington a statement of exceptions to the Trial Examiner's report. This statement of exceptions need follow no definite form but must indicate the particular respects in which the Report is deemed to be incorrect. Such exceptions must be filed within ten days from service upon the parties of the Intermediate Report. The Board reserves to itself the privilege of reopening the record at a later

${ }^{24}$ Rules and Regulations Series I as amended, Article II, Sec. 3 r. 
date to permit the party who made the charge to file exceptions, where such party by motion made within a reasonable time shows good cause for this action. ${ }^{25}$

Because of the careful investigation that is made by the Regional Staff of the Board before a complaint is issued, it has been the Board's experience that in most instances cases which finally come to hearing have merit. In most of the cases which Trial Examiners have heard, they have found that respondents actually engaged in unfair labor practices affecting commerce. ${ }^{26}$ Where such a finding is made, the Intermediate Report must contain, in addition to the findings of fact and conclusions of law, recommendations regarding the affirmative action which should be taken by the respondent to bring about a condition in harmony with the law. The Intermediate Report usually recommends further that, if the respondent does not take such affirmative action and does not cease and desist from the practices set forth in the report, the Board should proceed further with the case and issue an order directing the respondent so to cease and desist and to take the affirmative action outlined by the Trial Examiner. Three possible courses may then result. If the respondent follows the recommendations of the Trial Examiner, the case is closed unless the party filing the charge has deemed the recommendation of the Trial Examiner unsatisfactory and has filed exceptions to it. Secondly, the respondent may take no affirmative action either by way of compliance or the filing of exceptions. Lastly, the respondent may file exceptions to the Intermediate Report, setting forth the specific grounds of its objection to that Report.

When either party files exceptions to the Trial Examiner's report or when the Trial Examiner has recommended certain affirmative action and this action has not been taken, the case is transferred to the Board in Washington. The Board then has the power to decide the matter forthwith upon the record, to reopen the record and direct the taking of further evidence, or to decide the matter after receiving briefs or hearing oral argument. Usually the Board decides the case upon the record unless either party requests permission to file briefs or to present oral argument. Hearings for the purpose of oral argument are scheduled before the Board in Washington and requests for such hearings or for permission to file briefs are almost always granted.

After a case has been transferred to the Board, an independent review of all the facts in the record is made, and the Board issues its decision on

25 Ibid.

${ }^{26}$ For the same reason most of the decisions issued by the Board have been against the employers involved. 
the basis of these facts. Where the Board finds that no unfair labor practices have been committed, the complaint is dismissed and the case closed. Where the Board finds that the respondent has engaged in one or more unfair labor practices, it issues its decision, setting forth complete findings of fact and conclusions of law, together with an order directing the respondent to cease and desist from the unfair labor practices and further directing that the respondent take whatever affirmative action the Board deems necessary to overcome the effects of the unfair labor practice and to effectuate the policies of the Act. ${ }^{27}$ The affirmative action ordered by the Board may involve the reinstatement of discharged employees, with back pay from the time of their discharge, the posting of notices in the plant stating that the employer will not interfere with the rights of its employees, the disestablishment of relations with a company union and withdrawal of recognition from it, or any one of a number of other acts which the Board believes would, in the particular case, nullify the effects of the unfair labor practice engaged in by the employer. ${ }^{28}$

\section{REPRESENTATION CASES}

A representation case is really a preliminary proceeding, and a certification by the Board is not a "final order" within the meaning of Section Io (f) of the National Labor Relations Act. ${ }^{29}$ The determination of who is chosen by employees to represent them for the purpose of collective bargaining is valueless except as a prerequisite to collective bargaining. Frequently a refusal of an employer to bargain with a Union on behalf of his employees is based on the employer's claim of lack of knowledge of the Union's right to represent his employees. Sometimes this claim is specious and the Board has rejected it as an excuse for a refusal to bargain. In some complaint cases, the Board has accepted satisfactory evidence that the representative claiming to speak for the employees actually was the chosen representative of the majority, and has thus avoided the necessity of a representation proceeding. ${ }^{30}$

After a determination of whom the employees desire to represent them for collective bargaining, there may still arise a refusal on the part of the employer to bargain with the designated representative. In such a case, a charge that the employer has engaged in an unfair labor practice within

${ }^{27}$ N.L.R.A. Sec. Io (C).

${ }^{28}$ Second Annual Report of the National Labor Relations Board, I44 et seq. (I937).

${ }^{29}$ See decision of Judge McLaughlin (Supreme Court, New York County) in the case of Wallach's, Inc., dated January 17, 1938, deciding a similar question under the New York State Labor Relations Act.

${ }^{30}$ In the Matter of Delaware-New Jersey Ferry Co. and Marine Engineers Beneficial Association No. 13 I N.L.R.B. 85 (1935); In the Matter of Rabhor Co., Inc. and International Ladies Garment Workers Union I N.L.R.B. $47^{\circ}$ (1936). 
the meaning of Section 8 (5) of the Act would be brought and the procedure for complaint cases would be followed.

Although legally the determination of representatives is not a final order of the Board, in practice it frequently results in a termination of the controversy between the parties. It is interesting to note that almost $30 \%$ of all representation cases pending before the Board during the period from July I, I936, to June 30 , I937, resulted in settlement either by the holdings of consent elections or by recognition of representatives without any election procedure being used.

A representation case is instituted by the filing of a petition with a Regional Director, requesting the Board to investigate and certify the name of the representative selected for the purpose of collective bargaining. The National Labor Relations Act does not specify the means by which the representation machinery of the Board can be set in motion. The Board itself, in its rules and regulations, has restricted the initiation of such a procedure by providing that a petition may be filed by "any employee or any person or labor organization acting on his behalf." ${ }^{3 x}$ This regulation prevents an employer from filing on his own behalf a petition requesting the Board to investigate the question of representation. Experience of the National Labor Relations Board and of its predecessor Board clearly indicated the desirability of this limitation to prevent the use of the Act in a manner which would defeat its purposes, particularly where union organization has just commenced in the employer's plant.

The petition requesting certification of representatives must contain the name and address of the petitioner and of the employer, the nature of the employer's business, and the number of his employees, a description of the bargaining unit alleged to be proper and the number of employees therein, the number of employees whom the petitioner claims to represent within that unit, and the names of other individuals or labor organizations who claim to represent those employees. ${ }^{32}$ This petition must be fled with the Regional Director for the region in which the contemplated bargaining unit exists.

The Act provides that "whenever a question affecting commerce arises concerning the representation of employees, the Board may investigate such controversy." ${ }^{33}$ It would thus seem to be necessary for the Board to determine whether a question affecting commerce concerning the representation of employees has arisen before an investigation of the controversy could be made. In actual practice this is, of course, impossible.

${ }^{3 x}$ Rules and Regulations Series $I$ as amended, Article III, Sec. I.

${ }^{32} \mathrm{Id}$. at Sec. 2.

${ }_{33}$ N.L.R.A. Sec. 9 (c). 
Some preliminary investigation must be made before the Board can determine that the type of investigation contemplated by the statute should be instituted. The Board has therefore instructed its Regional Directors to make a preliminary investigation as soon as a petition is filed with them. If the investigation reveals that there may be a question concerning representation and that the matter falls within the jurisdiction of the Board, the Regional Director so reports and the Board authorizes the Director to proceed with a formal investigation. If the Director's preliminary investigation reveals that there may be a question concerning representation and that the matter falls within the jurisdiction of the Board, the Regional Director so reports and the Board authorizes the Director to proceed with a formal investigation. If the Director's preliminary investigation reveals that there is no question concerning representation or that the question concerning representation does not affect commerce, the Director recommends to the Board that the petition be dismissed and informs the person who filed the petition of his recommendation. The.Board will then review the available facts and will determine whether to dismiss the petition. If in its opinion the Regional Director's recommendation is justified, the petition is dismissed forthwith and the case is closed.

As in complaint cases, the Regional Director or the Field Examiner, while making the preliminary investigation, attempts to avoid the necessity for formal action by trying to arrange a satisfactory adjustment of the dispute. This may take the form of an admission on the part of the employer that the petitioner represents the employees for the purpose of collective bargaining, and may sometimes result in the signing of a collective bargaining agreement between the petitioner and the employer. Frequently, the Regional Director is able to arrange a consent election by secret ballot. In such cases, an agreement is entered into between the parties providing for the balloting, the terms and methods of the election, the form of ballot and election notice, the time and place of ballot, and as many other details as the parties can agree upon. All consent election agreements provide that the election to be held thereunder is to be in conformance with the rules and regulations of the Board with regard to the elections and that the Regional Director is to determine any disputed questions which may arise. Another device used to settle the question of representation is the checking of payroll lists against Union membership cards or applications by a person acceptable to both parties, and a statement by such person of the number of employees in the Union. I have 
stated before that approximately $30 \%$ of the total number of representation cases before the Board in the twelve-month period ending June 30 , I937, were settled by agreement of the parties. Since more than half of the representation cases before the Board in that period were still pending on June 30,1937 , the cases closed by settlement actually represent about two-thirds of all representation cases closed.

Where no settlement of the dispute can be reached and the petition is not withdrawn by the party filing it or dismissed by the Board before hearing, the Regional Director sends the parties a notice of hearing, together with a copy of the petition. The hearing in a representation case is similar in most respects to the hearing in a complaint case. It is conducted by a Trial Examiner sent from the Washington office of the Board. The rules regarding motions, adjournments, evidence and similar matters are the same as the rules for complaint cases. One important difference should be noted, however. In a complaint case the complaint is issued in the name of the Board and the respondent is charged with having violated a law of the United States. In a representation case no violation of law is charged and the Board is under the duty to do no more than prove it has jurisdiction over the subject matter. The Regional Attorney does not participate in the representation hearing, except for the purpose of proving jurisdiction, or sometimes clarifying the issues so that the hearing proceeds without too great confusion. The Trial Examiner, however, remains under the duty to see that the record contains all the essential facts involved and for this purpose can call, examine, and cross-examine witnesses.

Upon completion of the hearing, the Trial Examiner, instead of sending an Intermediate Report to the parties, makes an informal report directly to the Board in Washington. This informal report is not a part of the record in the case and is not available to the parties. Upon receipt of the informal report, the Board proceeds to a consideration of the record and if in its opinion no controversy regarding representation exists, or the controversy does not affect commerce, it dismisses the petition. If from the record it is apparent that the jurisdictional requirements are met, the Board issues its decision, setting forth the proper bargaining unit and either directing an election or certifying the representatives of the employees in that unit. Where an immediate certification is made, the case is closed upon the issuance of the certification to the parties.

Usually it is necessary to direct that an election shall be held within a specified time. The Direction of Election lists the classes of employees 
who are eligible to vote and states what payroll date shall be used as the basis of the eligibility list. The Direction of Election orders the Regional Director in the region in which the controversy arose to conduct the election as agent of the Board, and the Regional Director is expected to make all the necessary arrangements for notices of election, printing of ballots, posting of eligibility lists, polling places, and similar details.

Upon completion of the vote, the ballots are counted in the presence of representatives of the parties and the Regional Director sends to the Board an Intermediate Report containing a tally of the ballots and the Director's findings and recommendations. This Intermediate Report is served upon the parties, who then have five days within which to object to the ballot or the report. If such objection is filed and the Regional Director believes that the objection raises "a substantial and material issue with respect to the conduct of the ballot," ${ }_{34}$ he issues a notice of hearing on the objections. The hearing is conducted by a Trial Examiner, who then prepares and files with the Regional Director a report containing his findings and recommendations regarding the objections. When this report is filed or, where no objections have been raised, when the five-day period for the filing of objections has expired, the full record of the case is forwarded to the Board in Washington.

Upon receipt of the report on the secret ballot and after hearing any oral argument which the parties may desire to make regarding the conduct of the election, the Board issues an order certifying the representative chosen by the employees in those cases where the results of the ballot were conclusive, or dismissing the petition if the petitioner lost the election and the choice on the ballot was limited to the one representative. In some cases, a further election may be necessary, since the Board, where there are two representatives named on the ballot, also provides an opportunity for employees to express their desire to have neither of the representatives act for them in collective bargaining. If neither of the two representatives secured a majority of the votes, and if the majority of the employees did not express their desire for representation by neither of these two representatives, the Board orders a further election in which the employees can vote for or against the representative polling the highest number of votes. After this further election is held, the procedure followed by the Board would be similar to that just described. Upon the issuance of a certification of representatives for the purpose of collective bargaining, the case is closed, a certification being the final action in a representation case.

34 Rules and Regulations Series I as amended, Article III, Sec. 9. 


\section{GENERAL PROCEDURE}

In both complaint cases and representation cases, the Board reserves to itself the right to permit parties to file a charge or petition directly with it in Washington, when it deems such procedure necessary in order to effectuate the purposes of the Act. Sometimes a charge is filed against an employer covering a plant of sufficiently great magnitude, or involving a question of sufficiently great importance, to require the direct and immediate attention of the Board itself. Sometimes a matter may involve plants located in several regions. In such instances, the parties may make a motion requesting permission to file the charge or petition directly with the Board.

The Board has the right under its rules and regulations to transfer a case to itself at any time during the course of the proceedings, as well as to permit a case to be filed directly with it at the commencement of the proceedings. The Board may also consolidate a case which has been commenced in one region with another proceeding which has been instituted in the same region or in some other region. It may transfer a case from one region to another for any purpose. Such steps may be taken "whenever the Board deems it necessary in order to effectuate the purposes of the Act." 35 In those cases in which the Board transfers the proceedings to itself, it exercises all the powers and functions which would usually be exercised by Regional Directors if the cases had remained in the various regions.

The Act provides that the hearing which must be held in a representation case can be held in conjunction with a proceeding under Section ro of the Act, and the rules and regulations contain a similar provision..$^{36}$ Frequently a Union will file a charge that an employer has engaged in an unfair labor practice by refusing to bargain collectively with it and will at the same time file a petition requesting certification. Sometimes the petition requesting certification is filed with a charge that an employer has formed an alleged company union. In almost every case where a petition and charge are filed against the same employer, the Board directs that a joint hearing be held covering both proceedings. In cases where the evidence shows that the Union had a clear majority, the petition may be dismissed and the Board may find that there was a refusal to bargain on the part of the employer. ${ }^{37}$ In some instances, it is necessary to hold the

35 Rules and Regulations Series I as amended, Article II, Sec. 37, and Article III, Sec. ro. ${ }^{36}$ N.L.R.A. Sec. 9 (C).

37 In the matter of Atlantic Refining Co. and Local Nos. 3 IO and $3^{18}$ International As. sociation of Oil Field, Gas Well, and Refinery Workers of America I N.L.R.B. 359 (I936). 
decision in the complaint case in abeyance until an election has been held in the representation case. As a practical matter, the Board has frequently found that holding joint hearings on petitions and charges simplifies and expedites the Board's procedure.

\section{ENFORCEMENT PROCEDURE}

In those cases in which the Board has issued a cease and desist order and the respondent has refused to comply with the order and to take the affirmative action required, the Board files a petition with the United States Circuit Court of Appeals within any circuit where the unfair labor practice occurred, or where the respondent resides or transacts business, for the enforcement of its order and for appropriate temporary relief or restraining order.$^{38}$ The Board must thereupon certify and file with the court a transcript of the record in the proceedings and the Court is directed to serve notice of such filing upon the respondent. After this notice has issued, the court assumes jurisdiction of the proceedings.

The court has power to grant to the Board temporary relief or a temporary restraining order. This power has not yet been exercised by any Circuit Court of Appeals, although the Board in several instances has made application for such relief. The Act provides that the petitions filed by the Board or by a party "shall be heard expeditiously and if possible within ten days after they have been docketed." 39 In most instances this has been nothing more than a pious hope. Usually many months elapse between the time of the filing of the petition and the hearing of argument.

Any person aggrieved by a final order of the Board which grants or denies the relief sought may also petition the proper Circuit Court of Appeals, or the Court of Appeals of the District of Columbia, praying that the order of the Board be modified or set aside. When a copy of this petition is served upon the Board, the aggrieved party must file with the court a transcript of the record in the proceedings, certified by the Board. The court in such cases can grant the Board temporary relief or a restraining order, just as though the Board rather than the aggrieved person had filed the petition.

After a petition has been filed for enforcement or modification of an order of the Board, either party can apply to the court for leave to adduce additional evidence. If it can be shown that the evidence is material and

${ }^{38}$ N.L.R.A. Sec. xo (E). The Act provides that when the Circuit Courts of Appeals are in vacation, the Board may apply for enforcement of its order to any District Court of the United States within the district in which the unfair labor practice occurred or within which the respondent resides or transacts business.

39 N.L.R.A. Sec. ro (I). 
there were reasonable grounds for failure to adduce it at the hearing before the Board, the court may direct the Board to hold a further hearing and take such evidence. The Board may thereafter make new findings or modify its previous findings and these new or modified findings are thereupon filed with the court.

The court then proceeds to a consideration of the case and schedules a hearing. It has no right to consider any objection which has not been urged before the Board or its agent, unless the party attempting to raise such objection can show that extraordinary circumstances existed which would excuse the failure or neglect to urge these objections. The court does not have the right to set itself up as a trier of the facts. The Act provides that "the findings of the Board as to the facts, if supported by evidence, shall be conclusive." ${ }_{40}$

The jurisdiction of the Circuit Court is exclusive and its judgment and decree is final, except that such judgment and decree is subject to review by the Supreme Court of the United States upon writ of certiorari or certification. If no appeal is taken from the judgment and decree of the Circuit Court, a failure to comply therewith is deemed a contempt of court and punishable as such. It is worth noting that until such judgment or decree has been rendered by the Circuit Court no real penalty for a violation of the Act has been incurred.

\section{CONCLUSIONS}

The only fair tests to apply to the administrative procedure evolved by the Board are the tests of efficiency and fairness. There has been no claim that the Board's procedure is inefficient. Despite the fact that the rules and regulations of the Board were originally prepared at a time when there was no real experience to use as a guide, the procedure outlined in the rules and regulations has stood the test of actual practice remarkably well.4I There is some delay in the handling of cases and delay is, of course, undesirable, particularly in cases dealing with labor relations. However, it is difficult to see where the process followed by the Board could be shortened without sacrificing the rights of the parties.

This brings us to the question of the fairness of the Board's procedure. On this point it is best to permit the Supreme Court of the United States

${ }^{40}$ N.L.R.A. Sec. Io (E). See Washington, Virginia, and Maryland Coach Company vs. National Labor Relations Board, 301 U.S. 142 (1937).

4x In April of 1937 the Board issued an amendment to its Rules and Regulations. The rules were amended only in minor details and the Board's procedure remained essentially unchanged. 
to speak. In the Jones $\mathcal{F}^{\circ}$ Laughlin case, ${ }^{42}$ Chief Justice Hughes, speaking for the majority of the court, stated:

The procedural provisions of the Act are assailed. But these provisions, as we construe them, do not offend against the constitutional requirements governing the creation and action of administrative bodies. See Interstate Commerce Commission v. Louisville \& Nashville R. Co., 227 U.S. 88, 9x. The Act establishes standards to which the Board must conform. There must be complaint, notice and hearing. The Board must receive evidence and make findings. The findings as to the facts are to be conclusive, but only if supported by evidence. The order of the Board is subject to review by the designated court, and only when sustained by the court may the order be enforced. Upon that review all questions of the jurisdiction of the Board and the regularity of its proceedings, all questions of constitutional right or statutory authority are open to examination by the court. We construe the procedural provisions as affording adequate opportunity to secure judicial protection against arbitrary action in accordance with the well-settled rules applicable to administrative agencies set up by Congress to aid in the enforcement of valid legislation.

${ }_{42}$ zor U.S. I, 46 (I937). 